\title{
PENYULUHAN PENCEGAHAN COVID-19 DENGAN PENGGUNAAN MASKER DAN PELINDUNG ANTI AIR PADA PERANGKAT TELEPON GENGGAM
}

\author{
Estu Sinduningrum¹), Dan Mugisidi²), Atiqah Meutia Hilda') \\ 1)Program Studi Teknik Informatika, Fakultas Teknik, Universitas Muhammadiyah Prof.Dr.Hamka, Pasar rebo, \\ Jakarta Timur, Indonesia \\ 2)Program Studi Teknik Mesin, Fakultas Teknik, Universitas Muhammadiyah Prof.Dr.Hamka, Pasar rebo, \\ Jakarta Timur, Indonesia \\ Corresponding author: Estu Sinduningrum \\ E-mail : estu.ningrum@uhamka.ac.id
}

Diterima 11 Juni 2021, Direvisi 24 Juli 2021, Disetujui 25 Juli 2021

\begin{abstract}
ABSTRAK
Penggunaan ponsel saat ini sangat diperlukan, bahkan dalam kondisi pandemi COVID-19 saat ini. Masyarakat belum sadar akan bahaya penggunaan telepon seluler (HP) dalam situasi pandemi, seperti penggunaan HP pada transportasi umum (bus, kereta api, dsb), rumah sakit, dll. Pengguna HP saat di angkutan umum sering mengoperasikan HP sedangkan mungkin lupa sebelumnya telah memegang palang besi atau pintu bus sehingga HP menjadi terkontaminasi virus COVID-19. Melihat venomena ini oleh tim pengabdian masyarakat (PKM) tergerak untuk mensosialisasikan penggunaan pelindung telepon seluler tahan air dan cara membersihkan telepon seluler (HP) setelah digunakan dalam perjalanan atau diluar rumah. Kegiatan pengabdian masyarakat dilakukan saat lockdown dilaksanakan di Jakarta, maka dari itu tim melakukan sosialisasi dengan menggunakan brosur dan penyaluran bantuan kepada petugas kesehatan. Pengabdian masyarakat selain memberikan sosialisi pencegahan virus melalui perangkat HP, tim PKM memberikan menjelaskan kembali perlunya menjaga protokol kesehatan dengan memakai masker, serta cuci tangan menggunakan handsanitaizer. Tim PKM juga tergerak untuk memberikan bantuan kepada masyarakat kurang mampu yang bermukim di jalanan kawasan Cibubur dan sekitarnya. Hasil sebelum sosialisasi melalui survei dilapangan didapatkan $35 \%$ pasien dan 30\% perawat menyatakan Telah mengetahui sebelumnya bahwa penggunaan pelindung Handphone (HP) diperlukan untuk pencegahan Covid-19. Hasil setelah sosialisasi melalui brosur, bahwa cara-cara pelindungan perangkat HP demi pencegahan Covid-19 sangat mudah dimengerti didapatkan hasil Pasien $93,33 \%$ dan perawat $95 \%$. Para perawat sebesar $97.5 \%$, dan $96.67 \%$ pasien berharap penjelasan Perlindungan HP ini perlu disosialisasikan lebih luas.
\end{abstract}

Kata kunci: pandemi covid-19; perlindungan tahan air; bersihkan ponsel.

\begin{abstract}
The use of mobile phones today is indispensable, even in the current state of the COVID-19 pandemic. People are not aware of the dangers of using cell phones (HP) in a pandemic situation, such as using cellphones on public transportation (buses, trains, etc.), hospitals, etc. HP users when on public transport often operate their cellphones while they may forget that they have previously held iron bars or bus doors so that their cellphones become contaminated with the COVID-19 virus Seeing this phenomenon, the community service team (PKM) was moved to socialize the use of waterproof cell phone protectors and how to clean cell phones (HP) after being used on a trip or outside the home. Community service activities were carried out when the lockdown was implemented in Jakarta, therefore the team carried out socialization by using brochures and distributing aid to health workers. Community service in addition to providing socialization on virus prevention through mobile devices, the PKM team also explained the need to maintain health protocols by wearing masks, and washing hands using a hand sanitizer. The PKM team was also moved to provide assistance to underprivileged communities who live on the streets of the Cibubur area and its surroundings. The results before the socialization through a field survey showed that $35 \%$ of patients and $30 \%$ of nurses stated that they had known beforehand that the use of a mobile phone (HP) protector was needed to prevent Covid-19. The results after socialization through brochures, that the ways to protect HP devices for the prevention of Covid19 are very easy to understand, the results are $93.33 \%$ patients and $95 \%$ nurses. $97.5 \%$ of nurses, and $96.67 \%$ of patients hope that this explanation of HP Protection needs to be disseminated more widely.
\end{abstract}

Keywords: covid-19 pandemic; waterproof protection; clean the cell phone 


\section{PENDAHULUAN}

Pandemi corona virus baru (SARSCOV-2) atau covid-19 yang melanda seluruh dunia pada desember 2019, yang berasal dari Wuhan, Cina,kini telah menyebar ke 113 negara dan teritori di luar Cina (Huang et al. 2020). Jakarta mulai melakukan lockdown di bulan maret 2020 . Masyarakat saat itu belum mengetahui banyak hal mengenai wabah covid19.

Tim pakar Fakultas Kesehatan Masyarakat Universitas Indonesia (FKM UI) menilai prediksi virus Corona telah masuk ke Indonesia sejak minggu ke-3 Januari 2020 (detikNews 2020).

Virus Corona adalah bagian dari keluarga virus yang menyebabkan penyakit pada hewan ataupun juga pada manusia. Di Indonesia, masih melawan Virus Corona hingga saat ini, begitupun juga di negaranegara lain. Jumlah kasus Virus Corona terus bertambah dengan beberapa melaporkan kesembuhan, tapi tidak sedikit yang meninggal. Usaha penanganan dan pencegahan terus dilakukan demi melawan COVID-19 dengan gejala mirip Flu.

Sebagai manusia yang merupakan makhluk sosial pastinya saling membutuhkan satu sama lain. Manusia tidak pernah tahu kapan kesulitan akan dialami atau tertimpa ke pada orang lain. Tetapi, pasti setiap orang akan melalui jalan yang sulit, sehingga membutuhkan bantuan atau pertolongan dari orang lain. Setiap orang akan dihadapkan dengan persoalan yang tidak mampu dihadapinya sendiri tanpa melibatkan orang lain untuk membantunya. Karena itu, pastinya dalam hidup ini harus saling membantu dan menolong.

Jangan pernah meremehkan kebaikan, sekecil apa pun. Jika orang lain terlihat malas berbuat baik, bantu dan tolonglah dia untuk melakukan kebaikan. Jika orang lain dalam kesusahan dan kesulitan hidup, bantulah dengan kebaikan, misalnya, dengan bersedekah, memberi utang, memberi nasihat solutif yang mampu menyelesaikan persoalannya dan mengangkatnya dari jurang penderitaan. Semua ini dalam rangka berbuat baik untuk mendapatkan kebaikan dari Allah yang sangat besar, tidak hanya di dunia, tetapi juga di akhirat kelak.

Dalam hadis, Nabi mengatakan, "Barang siapa melepaskan kesusahan seorang Muslim dari kesusahan dunia, Allah akan melepaskan kesusahannya pada hari kiamat. Barang siapa memudahkan orang lain yang mendapat kesusahan, Allah akan memudahkan urusannya di dunia dan akhirat. Barang siapa menutupi aib seorang Muslim, Allah akan menutupi aibnya di dunia dan di akhirat. Sesungguhnya, Allah selalu akan menolong hamba- Nya selama ia menolong saudaranya (HR Muslim)".

Saling membantu atau menolong ini tentunya dalam hal kebaikan, bukan dalam keburukan dan kejahatan. Allah berfirman, "Dan tolong-menolonglah kamu dalam (mengerjakan) kebajikan dan takwa, dan jangan tolong-menolong dalam berbuat dosa dan pelanggaran. Dan bertakwalah kamu kepada Allah, sesungguhnya Allah amat berat siksa-Nya." (QS al-Ma'idah [5]: 2).

Himbauan pemerintah terhadap warganya untuk melakukan social distancing dan isolasi untuk mencegah penyebaran virus yang dapat terjadi melalui beberapa penyebaran secara contagious (Mona 2020). Penggunaan perangkat telepon genggam atau telepon seluler (HP) di lingkungan kerja pada situasi covid-19 saat ini sangat dibutuhkan meski telah diketahui bahwa virus corona dapat bertahan pada benda mati seperti HP selama 5 hari (kompas.com 2020). Handphone menjadi salah satu medium penyebaran virus corona, karena rendahnya kesadaran masyarakat saat menggunakan handpone saat berada di transportasi publik (Sindo 2020). Melihat kurangnya pengetahuan masyarakat akan bahayanya penggunaan HP disituasi pandemi ini maka dari itu tergerak untuk melakukan sosialisasi penggunaan pelindung anti air serta bagimana cara membersihkan HP setelah digunakan dalam perjalanan ataupun saat diluar rumah. Tim pengabdian masyarakat Uhamka, melakukan koordinasi dengan tiga mitra, yaitu perawat di puskesmas tebet Jakarta timur, catering makan siap santap, dan masyarakat sekitar Jl smu 99 Cibubur Jakarta timur. Pada awalnya tim pengabdian masyarakat dengan menggunakan dana pribadi dalam menolong warga di lingkungan sekitar rumah. Akan tetapi pada akhirnya terpikir untuk bekerja sama dengan catering yang ada di wilayah rumah untuk menyiapkan makanan siap santap yang dibagikan untuk orang-orang di sepanjang jalan wilayah cibubur dan sekitarnya. Melalui media komunikasi WA, dilakukan penawaran kepada warga mampu yang ada di group chat komunitas sekolah dan orang tua murid ataupun group dosen di kampus Fakultas tenik Uhamka, didapatkan beberapa donatur tetap yang bersedia bersedekah.

"Studi terbaru dari pemerintah Amerika Serikat mengungkapkan bahwa virus corona dapat bertahan di permukaan plastik dan stainless steel yang terkontaminasi hingga 2-3 hari. Dilansir dari situs resminya, Apple menyarankan untuk menggunakan tisu 
disinfektan yang mengandung alkohol 70 persen untuk membersihkan HP (Wisnubrata 2020)". Mengetahui perlunya memberikan informasi ini kepada masyarakat luas, maka tim berinisiatif untuk melakukan pengabdian masyarakat untuk sosialisasi dengan cara membuat brosur cara membersihkan HP sebagai salah satu solusi pencegahan covid- 19 . Lockdown juga memiliki sisi negatif seperti kecemasan yang memicu panic buying terutama pada barang-barang pokok seperti makanan hingga peralatan medis seperti masker dan hand sanitizer. Jika stok semakin menipis maka kelangkaan bisa terjadi dan ujung-ujungnya harga naik secara gila-gilaan. Dampak negatif lain dari lockdown adalah aktivitas ekonomi yang lumpuh, banyak orang menjadi pengangguran atau di PHK karena perusahaan bangkrut. Hal ini memicu turunnya produktivitas setiap orang. Aktivitas produksi dan suplai menjadi terganggu. Namun di sisi lain, karena warga masyarakat tetap tinggal di rumah konsumsi pun ikut merosot.

$\mathrm{Dr}$ Michelle $\mathrm{Au}$, spesialis anestesi dari Rumah Sakit Emory St Joseph's, Amerika Serikat (AS), Michelle juga menjelaskan kesehatan masyarakat adalah bagaimana cara mencegah terjadinya penularan penyakit yang semakin besar. Warga masyarakat sangat diharapkan agar tetap menjaga jarak, tetap di rumah, dan tidak melakukan perkumpulan agar penyebaran virus corona tidak semakin luas. Ahli mikrobiologi Charles Gerba dari universitas Arizona Amerika serikat mengingatkan bahwa ada banyak kesempatan virus menyebar, termasuk pada trasportasi umum (bus, kereta api, dsb). Perlunya menghindari penggunaan HP pada saat di transportasi umum, karena layar HP bisa menjadi tempar subur untuk kuman. Jari tangan yang kotor saat menyentuh tiang, lalu menyentuh layar HP, kemudian menyentuh pipi serta mulut saat menerima panggilan telephone (Ludhy Cahyana 2020). Tim pengabdian menargetkan untuk memberikan sosialisasi kepada masyarakat umum serta membantu petugas kesehatan dalam pengabdian masyarakat ini karena mereka harus dilindungi kesehatannya. Salah satu kebutuhan alat pengamanan selain baju APD (alat pelindung diri) adalah pelindung perangkat telepon seluler (HP) anti air. Kurangnya pengetahuan masyarakat, serta anggota tim medis saat itu bahwa HP dapat menjadi salah satu media penyebaran virus covid-19.

\section{METODE}

Analisis permintaan keperluan dari tenaga medis selama terjadinya corona, yaitu bertanya melalui alat komunikasi WA, mempelajari apa saja kebutuhan mereka, mengapa, dan manfaatnya bagi tenaga medis. Selain itu dilakukan kuesioner melalui form elektronik dengan pertanyaan, sebagai berikut (tabel 3).

Berikut strategi yang dipergunakan dalam pengabdian:

\section{Tahap I}

a). Pengambilan sampel menggunakan teknik pengambilan sesaat (Accidental / haphazard sampling (Jogiyanto 2012)), merupakan teknik pengambilan sampel yang dilakukan secara tiba-tiba berdasarkan siapa yang ditemui.

b). Metode dan instrumen pengumpulan data yang digunakan Enquiring yaitu teknik pengumpulan data melalui pertanyaan oleh tim. Teknik pengumpulan datanya dapat berupa wawancara dan angket (Rachmawati 2007).

c). Teknik pengumpulan data, yaitu dengan menggunakan wawacara melalui aplikasi WA. Serta langsung melakukan pemantauan situasi dan kondisi puskesmas serta jalan disekitar wilayah Cibubur Jakarta timur.

d). Perhitungan kuesioner dilakukan dengan metode skala likert yang memiliki dua cara pertanyaan untuk mengukur skala positif dan formulir pertanyaan negatif untuk mengukur skala negatif (Pranatawijaya et al. 2019).

\section{Tahap II}

a). Teknik pembelian barang, yaitu melalui pembelian online dan pengiriman paket secara langsung dari penjual barang hal ini dilakukan untuk mengurangi interaksi secara langsung.

b). Persiapan Makanan siap santap dengan bekerja sama pihak katering melalui komunikasi telepon, merencanakan pembagian makanan dengan rapat menggunakan zoom meeting.

c). Teknik Sosialisasi yang dilakukan yaitu dengan pembagian Brosur, pentingnya penggunaan pelindung anti air pada perangkat telepon gengam, dan vitamin $\mathrm{C}$ kepada petugas medis. Pembagian brosur, Masker dan makanan siap saji kepada kaum dhuafa.

d). Evaluasi kepuasan terhadap sosialisasi penggunaan pelindung HP melalui from elektronik kepada perawat dan pasien, kemudian menghitung kuesiner dengan metode skala likert.

\section{HASIL DAN PEMBAHASAN}

Hasil dari pengabdian masyarakat ini, yaitu: 


\section{Tahap I.}

Permasalahan yang terjadi menyadari pentingnya Social distancing dan phisical distancing, serta membantu penanggulangan dampak ekonomi terutama masyarakat Dhuafa. Metode pendekatan serta penyuluhan yang dilakukan, yaitu:

1. Sosialisasi dan komunikasi Dosen \& Mahasiswa yang tinggal di kawasan dengan tokoh masyarakat.

2. Dosen dan Mahasiswa menawarkan program aksi penanggulangan Covid-19 berbasis komunitas.

3. Dosen dan Mahasiswa menawarkan program aksi penanggulangan dampak ekonomi wabah Covid-19 berbasis komunitas.

4. Dosen dan Mahasiswa turut aktif menjadi bagian dari Tim Relawan di Lingkungan Komunitas.

Metode yang digunakan pada kegiatan ini dapat diperinci sesuai dengan tabel 1 .

Tabel 1. Tabel Materi dan Metode Kegiatan Sosialisasi Saat Pandemi Covid-19

\begin{tabular}{cc}
\hline Materi & $\begin{array}{c}\text { Metode } \\
\text { Kegiatan }\end{array}$ \\
\hline $\begin{array}{c}\text { Wawancara serta Kuisioner } \\
\text { Terhadap perawat dan pasien } \\
\text { di puskesmas }\end{array}$ & Tes individu \\
\hline $\begin{array}{c}\text { Pembagian Brosur, } \\
\text { handsitizer, multivitamin, serta } \\
\text { pelindung Hp }\end{array}$ & $\begin{array}{c}\text { Di lokasi } \\
\text { Puskesmas }\end{array}$ \\
\hline $\begin{array}{c}\text { Pembagian Makanan siap saji, } \\
\text { brosur, masker, handsanitizer } \\
\text { kepada dhuafa di jalan }\end{array}$ & $\begin{array}{c}\text { Di lokasi Jalan } \\
\text { raya }\end{array}$ \\
\hline $\begin{array}{c}\text { Pembagian paket sembako, } \\
\text { brosur, masker, handsanitizer } \\
\text { kepada warga yang } \\
\text { membutuhkan di sekitar } \\
\text { Jl.SMU 99 }\end{array}$ & $\begin{array}{c}\text { Di lokasi } \\
\text { padat penduduk }\end{array}$ \\
\hline $\begin{array}{c}\text { Evaluasi Kuesioner (angket) } \\
\text { terhadap perawat, warga, dan } \\
\text { pasien di puskesmas }\end{array}$ & Tes Individu \\
\hline
\end{tabular}

\footnotetext{
Cara Membersihkan HP agar Terbebas dari Virus COVID-19

1. Cabut semua kabel dan matikan handphone.

2. Copot atau lepaskan casing dan aksesoris lainnya yang terdapat pada ponsel

3. Bersihkan secara horizontal atau vertikal di layar sentuh ponsel dalam satu arah

berulang dengan tisu disinfektan.

4. Gerakan mulai dari sisi kiri layar dan usap lurus ke sisi kanan layar.

5. Jangan menggosok terlalu keras.

6. Hindari menggosok berlebihan bagian yang terbuka

7. Jangan lupa untuk membersihkan area belakang, seperti kamera belakang dan flash.

8. Bersihkan juga casing yang berbahan plastik dan gosok setiap permukaannya,

9. Biarkan alkohol menguap untuk mengeringkan casing sebelum dipasang kembali.

10.I ebih aman bisa menggunakan pelindung perangkat telepone genggam anti air.
}

Gambar 1. Brosur Cara membersihkan HP dari virus Covid-19
Membuat Brosur cara membersihkan HP dari virus covid-19. Berikut caranya dapat dilihat pada gambar 1 .

Adapun tahapan 1 dari pelaksanaan sosialisasi meliput:

a. Tahap awal dan hasil sosialisasi terhadap perawat. Pada tahap ini dilakukan survey lokasi tempat pembagian brosur (gambar 1) di puskesmas serta jalan di sekitar wilayah cibubur. Kuesioner awal terhadapan perawat dan pasien di puskesmas tebet jakarta timur, pertanyaan kuesioner sebelum dan sesudah pemberian brosur dapat dilihat dari tabel 3. Kuesioner diberikan secara acak terhadap perawat dan pasien.

Tabel 2. Keterangan Bobot Penilaian Untuk kuesioner

\begin{tabular}{cc}
\multicolumn{2}{c}{ kuesioner } \\
\hline & PILIHAN JAWABAN \\
\hline 4 & Sangat Setuju \\
\hline 3 & Setuju \\
\hline 2 & Cukup \\
\hline 1 & Kurang \\
\hline
\end{tabular}

Soal terdiri dari : 6 soal

Jumlah Audien $(A):=10$ Orang perawat, dan 15 pasien puskesmas.

Skor Ideal perawat $=($ Jumlah Audien $\times$ Skor Tertinggi) $=10^{\star} 4=40$.

Tabel 3. Pertanyaan kuesioner sebelum kegiatan

\begin{tabular}{clc} 
No & \multicolumn{1}{c}{ Pertanyaan } \\
\hline 1 & $\begin{array}{l}\text { Telah mengetahui sebelumnya bahwa } \\
\text { penggunaan pelindung Handphone (HP) } \\
\text { diperlukan untuk pencegahan Covid-19 }\end{array}$ \\
\hline 2 & $\begin{array}{l}\text { Telah mengetahui cara-cara pelindungan } \\
\text { perangkat HP demi pencegahan Covid- } \\
19\end{array}$ \\
\hline 3 & $\begin{array}{l}\text { Perlunya Sosialisasi dan alat } \\
\text { perlindungan HP yang tahan air untuk } \\
\text { pencegahan Covid-19 }\end{array}$ \\
\hline 4 & $\begin{array}{l}\text { Perlunya tambahan multivitamin demi } \\
\text { menjaga stamina tubuh selama } \\
\text { beraktivitas di pandemi Covid-19 }\end{array}$ \\
\hline 5 & $\begin{array}{l}\text { Perlunya makanan bergizi demi menjaga } \\
\text { kekuatan tubuh dari pandemi Covid-19 }\end{array}$ \\
\hline 6 & $\begin{array}{l}\text { Perlunya Sosialisasi masker, } \\
\text { handsanitaizer sebagai } \\
\text { pencegahan Covid-19 }\end{array}$ \\
\hline
\end{tabular}


Tabel 4. Hasil Kuesioner sebelum kegiatan terhadap perawat

\begin{tabular}{|c|c|c|c|c|c|c|c|c|c|c|c|}
\hline \multicolumn{12}{|c|}{$\begin{array}{c}\text { Kuesioner Sebelum Pengabdian Sosialisasi } \\
\text { Penggunaan Pelindung Handphone ke Perawat }\end{array}$} \\
\hline \multirow{2}{*}{ No } & \multicolumn{4}{|c|}{ Skor } & \multirow{2}{*}{$\begin{array}{l}\mathrm{N}- \\
\operatorname{Max}\end{array}$} & \multicolumn{4}{|c|}{ Jumlah skor } & \multirow{2}{*}{ Jml } & \multirow[t]{2}{*}{$(\%)$} \\
\hline & 1 & 2 & 3 & 4 & & 1 & 2 & 3 & 4 & & \\
\hline 1 & 8 & 2 & 0 & 0 & \multirow{6}{*}{40} & 8 & 4 & 0 & 0 & 12 & 30 \\
\hline 2 & 6 & 4 & 0 & 0 & & 6 & 8 & 0 & 0 & 14 & 35 \\
\hline 3 & 0 & 0 & 2 & 8 & & 0 & 0 & 6 & 32 & 38 & 95 \\
\hline 4 & 0 & 0 & 3 & 7 & & 0 & 0 & 9 & 28 & 37 & 92,5 \\
\hline 5 & 0 & 0 & 2 & 8 & & 0 & 0 & 6 & 32 & 38 & 95 \\
\hline 6 & 0 & 0 & 0 & 10 & & 0 & 0 & 0 & 40 & 40 & 100 \\
\hline \multicolumn{11}{|c|}{ Jumlah } & 467,5 \\
\hline \multicolumn{11}{|c|}{ Rerata Total (\%) } & 93,5 \\
\hline
\end{tabular}

Pada tabel 4 merupakan hasil perhitungan kuesioner sebelum melakukan sosialisasi pengabdian yang dihitung menggunakan skala likert, dari Kuesioner sebelum pkm ini didapatkan nilai $30 \%$ terhadap 10 orang perawat di tebet Jakarta Timur dengan pertanyaan bahwa "Telah mengetahui sebelumnya bahwa penggunaan pelindung Handphone (HP) diperlukan untuk pencegahan Covid-19", dari nilai tersebut dapat dikatakan bahwa dari para perawat yang membaca brosur, sudah mengetahui mengenai informasi bahwa perlunya perlindungan terhadap perangkat HP. Perawat menyatakan 35\% bahwa "Telah mengetahui cara-cara pelindungan perangkat HP demi pencegahan Covid-19". Perlunya sosialisasi dan alat perlindungan HP yang tahan air untuk pencegahan Covid-19 bernilai $95 \%$.

Tabel 5. Hasil Kuesioner sebelum kegiatan terhadap pasien

\begin{tabular}{|c|c|c|c|c|c|c|c|c|c|c|c|}
\hline \multicolumn{12}{|c|}{$\begin{array}{c}\text { Kuesioner Sebelum Pengabdian Sosialisasi Penggunaan } \\
\text { Pelindung Handphone ke Pasien }\end{array}$} \\
\hline \multirow{2}{*}{ No } & \multicolumn{4}{|c|}{ Skor } & \multirow{2}{*}{$\begin{array}{c}\text { N- } \\
\text { Max }\end{array}$} & \multicolumn{4}{|c|}{ Jumlah skor } & \multirow{2}{*}{ Jml } & \multirow{2}{*}{ (\%) } \\
\hline & 1 & 2 & 3 & 4 & & 1 & 2 & 3 & 4 & & \\
\hline 1 & 13 & 2 & 0 & 0 & \multirow{6}{*}{60} & 13 & 4 & 0 & 0 & 17 & 35 \\
\hline 2 & 0 & 1 & 2 & 12 & & 0 & 2 & 6 & 48 & 56 & 28,3 \\
\hline 3 & 0 & 0 & 1 & 14 & & 0 & 0 & 3 & 56 & 59 & 93,3 \\
\hline 4 & 0 & 1 & 1 & 13 & & 0 & 2 & 3 & 52 & 57 & 98,3 \\
\hline 5 & 0 & 0 & 1 & 14 & & 0 & 0 & 3 & 56 & 59 & 95 \\
\hline 6 & 10 & 4 & 1 & 0 & & 10 & 8 & 3 & 0 & 21 & 98,3 \\
\hline \multicolumn{11}{|c|}{ Jumlah } & 448,3 \\
\hline \multicolumn{11}{|c|}{ Rerata Total (\%) } & 89,67 \\
\hline
\end{tabular}

Pada tabel 5 merupakan hasil perhitungan kuesioner sebelum melakukan sosialisasi pengabdian yang dihitung menggunakan skala likert, dari Kuesioner sebelum pkm ini didapatkan nilai total $89,67 \%$ terhadap 15 orang pasien di tebet Jakarta Timur dengan pertanyaan bahwa "Telah mengetahui sebelumnya bahwa penggunaan pelindung Handphone (HP) diperlukan untuk pencegahan Covid-19", dari nilai tersebut dapat dikatakan bahwa dari para pasien yang membaca brosur, belum mengetahui mengenai informasi bahwa perlunya perlindungan terhadap perangkat HP. Pasien menyatakan $28.3 \%$ bahwa "Telah mengetahui cara-cara pelindungan perangkat HP demi pencegahan Covid-19". Perlunya sosialasi dan alat perlindungan HP yang tahan air untuk pencegahan Covid-19 bernilai 93.3\%.

\section{Tahap 2}

Persiapan brosur gambar 2 merupakan wujud kepedulian kampus kepada situasi saat ini yang tidak menentu sehingga diturunkanlah tim-tim dosen dalam membantu masyarakat di wilayah Jakarta. 


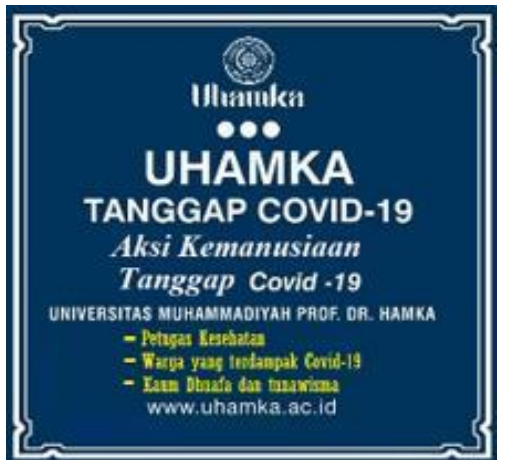

Gambar 2. Brosur Pengabdian Tim Uhamka Fakultas Teknik

Solusi yang dilakukan dalam menyelesaikan masalah yang terjadi dilapangan, yaitu:

1. Melihat perjuangan petugas medis, mengerakan hati nurani tim pengabdian untuk membantu sedikit meringankan beban mereka dengan memberikan brosur, masker, vitamin, dan pelindung telepon genggam anti air kepada petugas kesehatan. Memberikan bantuan kebutuhan penunjang kesehatan bagi tenaga medis. Melakukan Program aksi penanggulangan wabah Covid-19 pembagian multivitamin dan vitamin C (gambar 3).

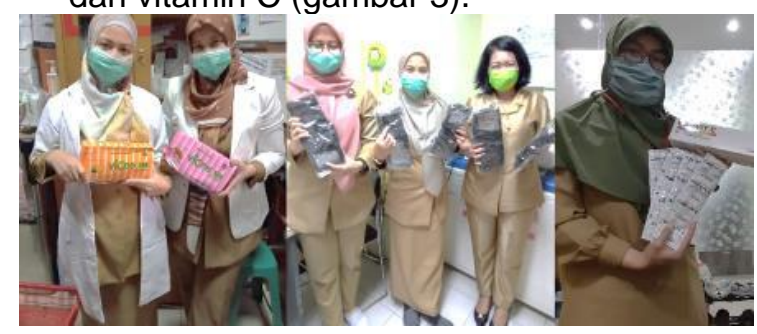

Gambar 3. Sosialisasi berupa brosur dan bantuan perlindungan diri kepada petugas kesehatan

2. Memberikan pelindung telepon genggam anti air kepada petugas medis di puskemas Jakarta timur dengan menggunakan brosur (gambar 1). Evaluasi yang dilakukan dengan form elektronik dengan pertanyaan di tabel 6. Hasil kuesioner terhadap perawat di tabel 7.
Tabel 6. Pertanyaan kuesioner sesudah kegiatan

\begin{tabular}{clc}
\hline No & \multicolumn{1}{c}{ Pertanyaan } \\
\hline 1 & $\begin{array}{l}\text { Telah Memahami Bahwa Pelindung } \\
\text { Handphone (HP) sangat bermanfaat untuk } \\
\text { pencegahan Covid-19 }\end{array}$ \\
\hline 2 & $\begin{array}{l}\text { Brosur cara-cara pelindungan perangkat HP } \\
\text { demi pencegahan Covid-19 sangat mudah } \\
\text { dimengerti }\end{array}$ \\
\hline 3 & $\begin{array}{l}\text { Penjelasan Alat pelindung HP yang tahan air } \\
\text { sangat diperlukan untuk pencegahan Covid- } \\
19\end{array}$ \\
\hline 4 & $\begin{array}{l}\text { Pemberian Multivitamin demi menjaga } \\
\text { stamina tubuh sangat terasa manfaatnya }\end{array}$ \\
\hline 5 & $\begin{array}{l}\text { Penjelasan Protokol kesehatan masker, } \\
\text { handsanitaizer sangat berguna bagi } \\
\text { pencegahan Covid-19 }\end{array}$ \\
\hline 6 & $\begin{array}{l}\text { Penjelasan Perlindungan HP ini perlu } \\
\text { disosialisasikan lebih luas }\end{array}$ \\
\hline
\end{tabular}

Tabel 7. Hasil Kuesioner setelah kegiatan terhadap perawat

\begin{tabular}{|c|c|c|c|c|c|c|c|c|c|c|c|}
\hline \multicolumn{12}{|c|}{$\begin{array}{l}\text { Kuesioner Sesudah Pengabdian Sosialisasi } \\
\text { Penggunaan Pelindung Handphone ke Perawat }\end{array}$} \\
\hline \multirow{2}{*}{ No } & \multicolumn{4}{|c|}{ Skor } & \multirow{2}{*}{$\begin{array}{l}\text { N- } \\
\text { Max }\end{array}$} & \multicolumn{4}{|c|}{ Jumlah skor } & \multirow{2}{*}{ Jml } & \multirow{2}{*}{ (\%) } \\
\hline & 1 & 2 & 3 & 4 & & 1 & 2 & 3 & 4 & & \\
\hline 1 & 0 & 0 & 1 & 9 & \multirow{6}{*}{40} & 0 & 0 & 3 & 36 & 39 & 97,5 \\
\hline 2 & 0 & 0 & 2 & 8 & & 0 & 0 & 6 & 32 & 38 & 95 \\
\hline 3 & 0 & 1 & 1 & 8 & & 0 & 2 & 3 & 32 & 37 & 92,5 \\
\hline 4 & 0 & 0 & 1 & 9 & & 0 & 0 & 3 & 36 & 39 & 97,5 \\
\hline 5 & 0 & 0 & 2 & 8 & & 0 & 0 & 6 & 32 & 38 & 95 \\
\hline 6 & 0 & 0 & 1 & 9 & & 0 & 0 & 3 & 36 & 39 & 97,5 \\
\hline \multicolumn{11}{|c|}{ Jumlah } & 477,5 \\
\hline \multicolumn{11}{|c|}{ Rerata Total (\%) } & 95,5 \\
\hline
\end{tabular}

Pada tabel 5 merupakan pertanyaan sesudah sosialisasi, sedangkan tabel 6 adalah hasil perhitungan kuesioner sesudah melakukan sosialisasi pengabdian yang menggunakan skala likert, dari Kuesioner sesudah pkm ini didapatkan nilai $97,5 \%$ terhadap 10 orang perawat di tebet Jakarta Timur menyatakan bahwa :

1. Telah Memahami Bahwa Pelindung Handphone (HP) sangat bermanfaat untuk pencegahan Covid-19 bernilai 97,5\%.

2. Perawat $95 \%$ menyatakan Brosur cara-cara pelindungan perangkat HP demi pencegahan Covid-19 sangat mudah dimengerti.

3. Perawat $92,5 \%$ menyatakan Penjelasan Alat pelindung HP yang tahan air sangat diperlukan untuk pencegahan Covid-19.

4. Perawat $97,5 \%$ menyatakan Pemberian Multivitamin demi menjaga stamina tubuh sangat terasa manfaatnya. 
5. Perawat 95\% menyatakan Penjelasan Protokol kesehatan masker, handsanitaizer sangat berguna bagi pencegahan Covid-19.

6. Perawat $97.5 \%$ berharap Penjelasan Perlindungan HP ini perlu disosialisasikan lebih luas.

Terhadap pasien hasil sosialisai ini dipilih secara acak pasien yang sedang berobat di puskesmas tebet Jakarta timur. Pertanyaan terhadap pasien sama dengan untuk perawat (tabel 6). Skor Ideal pasien $=($ Jumlah Audien $\mathrm{x}$ Skor Tertinggi) $=15^{\star} 4=60$. Hasil Kuesioner setelah kegiatan terhadap pasien dapat dilihat di tabel 8.

Tabel 8. Hasil Kuesioner setelah kegiatan terhadap pasien

\begin{tabular}{|c|c|c|c|c|c|c|c|c|c|c|c|}
\hline \multicolumn{12}{|c|}{$\begin{array}{l}\text { Kuesioner Sesudah Pengabdian Sosialisasi } \\
\text { Penggunaan Pelindung Handphone ke Pasien }\end{array}$} \\
\hline \multirow{2}{*}{ No } & \multicolumn{4}{|c|}{ Skor } & \multirow{2}{*}{$\begin{array}{c}\mathrm{N}- \\
\mathrm{Max}\end{array}$} & \multicolumn{4}{|c|}{ Jumlah skor } & \multirow{2}{*}{ Jml } & \multirow[t]{2}{*}{$(\%)$} \\
\hline & 1 & 2 & 3 & 4 & & 1 & 2 & 3 & 4 & & \\
\hline 1 & 0 & 0 & 2 & 13 & \multirow{6}{*}{60} & 0 & 0 & 6 & 52 & 58 & 96,67 \\
\hline 2 & 0 & 1 & 2 & 12 & & 0 & 2 & 6 & 48 & 56 & 93,33 \\
\hline 3 & 0 & 0 & 2 & 13 & & 0 & 0 & 6 & 52 & 58 & 96,67 \\
\hline 4 & 0 & 0 & 3 & 12 & & 0 & 0 & 9 & 48 & 57 & 95 \\
\hline 5 & 0 & 0 & 1 & 14 & & 0 & 0 & 3 & 56 & 59 & 98,33 \\
\hline 6 & 0 & 0 & 2 & 13 & & 0 & 0 & 6 & 52 & 58 & 96,67 \\
\hline \multicolumn{11}{|c|}{ Jumlah } & 480 \\
\hline \multicolumn{11}{|c|}{ Rerata Total (\%) } & 96 \\
\hline
\end{tabular}

Hasil perhitungan kuesioner di tabel 8 sesudah melakukan sosialisasi pengabdian yang menggunakan skala likert, dari Kuesioner sesudah pkm terhadap didapatkan nilai $96 \%$ terhadap 15 orang pasien di tebet Jakarta Timur menyatakan bahwa :

1. Telah Memahami Bahwa Pelindung Handphone (HP) sangat bermanfaat untuk pencegahan Covid-19 bernilai 96,67\%.

2. Pasien $93,33 \%$ menyatakan Brosur caracara pelindungan perangkat HP demi pencegahan Covid-19 sangat mudah dimengerti.

3. Pasien $96,67 \%$ menyatakan Penjelasan Alat pelindung HP yang tahan air sangat diperlukan untuk pencegahan Covid-19.

4. Pasien $95 \%$ menyatakan Pemberian Multivitamin demi menjaga stamina tubuh sangat terasa manfaatnya.

5. Pasien $98,33 \%$ menyatakan Penjelasan Protokol kesehatan masker, handsanitaizer sangat berguna bagi pencegahan Covid-19.

6. $96.67 \%$ berharap Penjelasan Perlindungan HP ini perlu disosialisasikan lebih luas.

7. Distribusi Bantuan pangan dan kebutuhan dasar keluarga dhuafa. Masyarakat menengah ke bawah karena kesadaran, fasilitas, dan juga kondisi ekonomi, yang mencari makan setiap hari, kalau tidak bekerja hari itu tidak makan. Mereka terpaksa bekerja meski dengan perut yang kelaparan, hal ini sangat memprihatinkan, oleh karena itu tim menyediakan makanan siap santap. Persiapan makanan siap santap, bagi orang dhuafa di jalanan dapat dilihat pada gambar 3. Pembagian sembako berupa lima barang kebutuhan pokok, yaitu: Beras, minyak goreng, gula pasir, susu kental manis, indomie, dan teh bagi warga yang membutuhkan pakan selama lockdown bertujuan agar membantu warga dari kelaparan disebabkan oleh dihentikan sementara pekerjaan dan diwajibkan untuk di rumah saja (gambar 4).

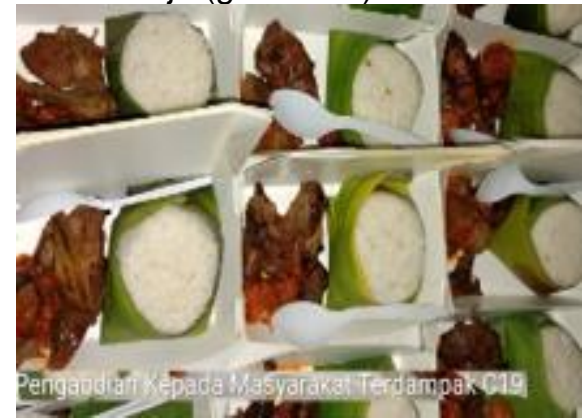

Gambar 4. Persiapan makanan siap santan

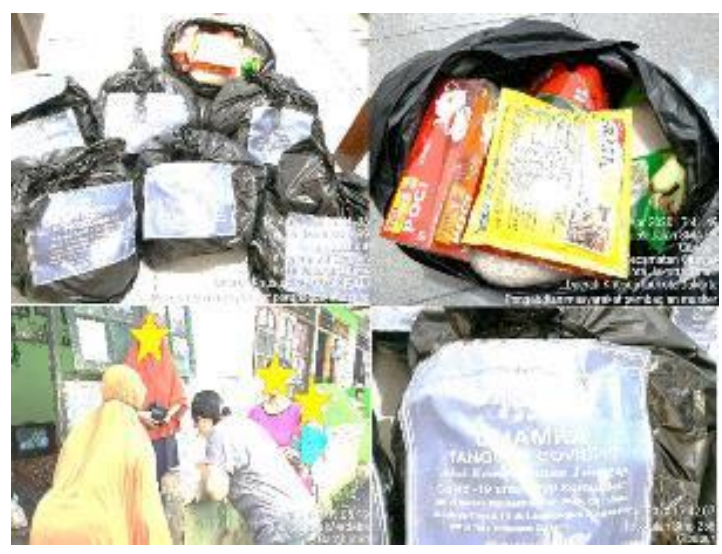

Gambar 5. Sosialisasi penggunaan masker dan bantuan sembako kepada warga

\section{SIMPULAN DAN SARAN}

Kegiatan ini merupakan salah satu wujud kepedulian tim dan semoga dapat membantu pemerintah dalam mengurangi angka penyebaran virus covid-19. Selain itu hasil dari sosialisasi yaitu membantu warga serta kaum dhuafa yang membutuhkan pangan, dan petugas kesehatan akan perlengkapan perlindungan diri, pengabdian ini juga menambah pengetahuan pencegahan virus covid-19 terutama pada penggunaan perangkat HP. 


\section{UCAPAN TERIMAKASIH}

Terimakasih kepada Dinas Kesehatan Puskesmas Tebet Timur. Dinas Keamanan Cibubur Taman $O$ Jakarta Timur. Catering Makan Kaum Dhuafa, LPPM Universitas Muhammadiyah Prof.Dr.Hamka (Uhamka). Seluruh tim Pengabdian Fakultas Teknik Uhamka.

\section{DAFTAR RUJUKAN}

detikNews. 2020. "Kapan Sebenarnya Corona Pertama Kali Masuk RI?" 26 April 2020. https://news.detik.com/berita/d4991485/kapan-sebenarnya-coronapertama-kali-masuk-ri.

Dyah Ika Rahmawati, Martha Suhardiyah. 2020. "ANALISIS FAKTOR-FAKTOR YANG MEMPENGARUHI MAHASISWA DALAM PEMILIHAN E-MONEY." Majalah ekonomi 25(1411): 1-11.

Huang, Chaolin et al. 2020. "Clinical Features of Patients Infected with 2019 Novel Coronavirus in Wuhan, China." Lancet (London, England) 395(10223): 497506.

Jogiyanto, H. 2012. Metodologi Penelitian Bisnis, Salah Kaprah Dan Pengalaman-Pengalaman. 5th ed. Yogyakarta: Badan Penerbit Fakultas Ekonomika \& Bisnis UGM.

kompas.com. 2020. "Virus Corona Yang Menempel Di 'Handphone' Bisa Bertahan 5 Hari.” 17 Juni 2020. https://nasional.kompas.com/read/202 0/06/17/13145671/dokter-virus-coronayang-menempel-di-handphone-bisabertahan-5-hari (March 13, 2021).

Ludhy Cahyana. 2020. "Tips Cegah Paparan Virus Saat Di Angkutan Umum." Tempo. https://travel.tempo.co/read/1315139/ti ps-cegah-paparan-virus-saat-diangkutan-umum/full\&view=ok.

Mona, Nailul. 2020. "Konsep Isolasi Dalam Jaringan Sosial Untuk Meminimalisasi Efek Contagious (Kasus Penyebaran Virus Corona Di Indonesia)." Jurnal Sosial Humaniora Terapan 2(2): 11725.

Pranatawijaya, Viktor Handrianus, Widiatry Widiatry, Ressa Priskila, and Putu Bagus Adidyana Anugrah Putra. 2019. "Penerapan Skala Likert Dan Skala Dikotomi Pada Kuesioner Online." Jurnal Sains dan Informatika 5(2): 12837.

Rachmawati, Imami Nur. 2007. "Pengumpulan Data Dalam Penelitian Kualitatif: Wawancara." Jurnal Keperawatan Indonesia 11(1): 35-40.

Sindo, Koran. 2020. "Waspada, Ponsel Bisa
Jadi Medium Penyebaran Virus Corona."

https://nasional.sindonews.com/read/7 4486/15/waspada-ponsel-bisa-jadimedium-penyebaran-virus-corona1592521578? showpage=all.

Wisnubrata. 2020. "Cara Membersihkan HP Agar Terbebas Dari Virus Corona." 26 Maret.

https://lifestyle.kompas.com/read/2020 /03/26/133840320/caramembersihkan-hp-agar-terbebas-darivirus-corona?page=all (March 13, 2021). 